\title{
SGURVY AND THE HEALTH OF EUROPEAN GREWS IN THE INDIAN OCEAN IN THE SEVENTEENTH CENTURY
}

\author{
by \\ F. J. TIGKNER, G.B.E., M.A., \\ AND V. G. MEDVEI, M.D., M.R.C.P.
}

Gaptain James Cook is commonly regarded as the pioneer in the use of antiscorbutics to ensure the health of a ship's crew on a long voyage; but there is considerable evidence that in the seventeenth century both the English, and more particularly the Dutch, East India Companies did a good deal to combat the effect of ill health amongst the crews of their ships.

Before the advent of modern methods of storage it was always difficult to carry supplies which offered an adequate range of diet on a long voyage, although the consequences of failure to do so have been understood from very early times. Nothing is known of the standards achieved by the Carthaginians in their attempts to explore the western seaboards of Europe and Africa; but on the earliest recorded occasion when European sailors attempted the navigation of the Indian Ocean, the voyage of the fleet of Alexander the Great from the mouth of the Indus to the head of the Persian Gulf in 329 B.c. under the command of Nearchus, the crews suffered severely from scurvy before the end of their journey.

Hippocrates referred to a large number of men in the army who suffered from pains in the legs, foetid breath, gangrene of the gums, and eventually lost their teeth. ${ }^{1}$ Medically, this seems to be a definite indication that those soldiers were suffering from scurvy. One of the reasons why the later Greek, Roman and Arabian (except perhaps Avicenna) physicians did not seem to have been acquainted with scurvy may be the fact that fruits and vegetables are so plentiful in those southern countries that scurvy must have been a disorder of rare occurrence on land and in the case of coast-bound seafaring which was usual in those days.

De Joinville gave an early description of scurvy at the time of the Crusades in the middle thirteenth century. ${ }^{2} \mathrm{He}$ again describes the spongy condition of the ulcerated gums and tells that the 'barber surgeons were forced to cut the dead flesh from the gums to enable the people to masticate their food'. He also describes the debility and the black spots on the legs. It may be of interest to note that the disease broke out in Lent during which time the Crusaders did not eat any meat but consumed a species of eel. But even before him there was an important observer 


\section{Scurvy and the Health of European Crews in the Indian Ocean}

who had some shrewd things to say concerning diet, and notably for those travelling at sea. These he urges to purify their drinking water, if necessary by distilling it through an alembic, he further advises them - seven hundred years in advance of our modern knowledge of vitamins - to be sure that they take on board with them plenty of dried grapes, apples and pears. ${ }^{3}$

This was Gilbert the Englishman (c. I165-1230), the 'Gilbertyn' mentioned by Chaucer as one of the authorities known to his Doctour of Phisyk."

In 1555 Olaus Magnus described the disease which flourished among the soldiers in camps and among prisoners in prisons in the northern parts of Europe. ${ }^{5}$

Amongst modern European peoples the Portuguese were the pioneers of Indian navigation, and casualties on board their ships were undoubtedly severe. The first Portuguese fleet to reach India, that of Vasca da Gama, who sailed from the Tagus with 16o men on 8 July I497, returned in August I498 with only fifty-five survivors. ${ }^{6}$ Few were killed in action, the majority of the deaths being caused by the disease which Camoens ${ }^{7}$ described so vividly in the $5^{\text {th }}$ canto of his Lusiad:

A dread disease its rankling horrors shed,

And death's dire ravage through mine army spread.

Never mine eyes such dreary sight beheld,

Ghastly the mouth and gums enormous swell'd,

And instant, putrid like a dead man's wound,

Poisoned with fetid steams the air around.

No sage physician's ever-watchful zeal, No skilful surgeon's gentle hand to heal

Were found: each dreary mournful hour we gave

Some brave companion to a foreign grave.

The next account, quoted in detail by Lind in his treatise, is that of Jacques Cartier, of his second voyage from St. Malo to Newfoundland with three ships in May 1535. The first voyage, with two ships, in the previous year was quick, short and successful, and the crews remained healthy. At Stadacona an 'unknown sickness' began to spread amongst his crew, which had afflicted and decimated the people of the said place.

Some did lose all their strength, and could not stand upon their feet; then did their legs swell, their sinews shrunk, and became as black as a coal. Others had also their skin spotted with spots of blood, of a purple colour. ... Their mouth became stinking; their gums so rotten that all the flesh came away, even to the roots of their teeth; which last did also almost all fall out.

The disease, which had started in December, reached its peak in February 1536 : by that time eight were dead, more than fifty near death's door, and only ten out of I Io still fit. A post-mortem examination was carried out in one case, but provided little information; finally an Indian told the captain about a native remedy which consisted of a decoction of the leaves and bark of the 'Ameda' or 'Hanneda' tree (this is thought to be the Sassafras tree). ${ }^{8}$

A description of what appears to have been dysentery and scurvy came from 


\section{F. F. Tickner and V. G. Medvei}

the Royal Navy in 1545, when the fleet was assembled in the Channel during the war with France. ${ }^{\circ}$

The most reliable account of a voyage to the East in the late sixteenth century is that of a Dutchman, Jan Huyghen van Linschoten, who sailed to India in the Portuguese service in $1583 .{ }^{10}$ His ship made Goa after a voyage of five months and thirteen days. Although she lost only thirty men on the way, by the time she reached India 'every man had been sick once or twice and let blood'. Little precaution seems to have been taken against the hot weather of the tropics. Linschoten says that 'at the equator we find a most extreme heat, so that all the water of the ship stinketh, whereby men are forced to stop their noses when they drink'. The only remedy attempted to restore the health of the crew was a call at Moçambique for fresh supplies, but even there many fell sick through the unhealthiness of the place itself.

The first Dutch fleet to sail for the East Indies left the Texel on 4 April 1595 . It consisted of four ships, the largest of which was of 200 tons, the smallest of 40 tons, and the crews numbered altogether 249 men. The first signs of scurvy appeared on 8 June after they had crossed the equator; and the first death, that of a ship's boy, occurred on I July. A daily ration of wine was then issued as an antiscorbutic; but to restore the health of their crews they spent from September I 595 until 3 February 1596 at various places in Madagascar. By this time there were only 127 men left in the fleet. They then crossed the Indian Ocean direct from Antongil Bay to Engano Island, off Sumatra. After calling at several ports in Java, principally at Bantam, they reached Bali at the end of the year. On 25 February 1597 their homeward journey began. They had now only eightyeight survivors of the original crews and eight recruits of various eastern nationalities. They reached home on I4 August I 597 after a better voyage, as they went south of Java and kept to cooler latitudes in the Indian Ocean; but when they came into the Texel one ship had not enough fit men on board to lower her anchors. 11

The lessons of this bad beginning were not lost on the organizers of the venture or on the officers of their second fleet of eight ships, which sailed in 1598. This time the crews fared decidedly better. There was some scurvy and dysentery in the fleet, but the flagship had only two fatal casualties on the voyage to Java, and the whole fleet lost only fifteen men on the way out.

The first English ship to reach the East Indies was the Edward Bonaventure, commanded by James Lancaster, and there are several references to scurvy in the account of her voyage in Hakluyt's Principal Voyages of the English Nation. The Edward Bonaventure fell into Spanish hands, but James Lancaster returned home safely to take command of the first fleet of the English East India Company, which sailed from Woolwich in I6or. Lancaster's principal pilot was the English navigator John Davis, recently returned from a voyage to Sumatra with a Dutch fleet. The English crews suffered so badly from the scurvy that 'the merchants took their turns at the helm'; but on board the flagship Lancaster took the precaution of carrying citrous fruit juice, and his crew kept in better health than those of the other ships. It is recorded that he 


\section{Scurvy and the Health of European Crewes in the Indian Ocean}

brought to sea with him certaine Bottles of the juice of limons, which he gave to each one, as long as it would last, three spoonfuls each morning, fasting, not suffering them to eate anything at all after it till noone. This juice worketh much the better if the partie keep a short Dyet, and wholly refraine salt meate, which salt meate, and long being at sea is the only cause of the breeding of this disease. By this meanes the Generall cured many of his men and preserved the rest. ${ }^{12}$

Like the Dutch navigators, the English called at Sainte Marie island off the east coast of Madagascar, where they 'had some store of limons and oranges, which were precious for our diseased men, to purge their bodies of the scurvy'.

Lancaster's knowledge was quickly applied by the Company so that the supply of fresh oranges and lemons and lemon-juice became official. In the 'First Letter-book of the East India Company' (I6oo-r9) this entry appears: 'A computacion of the chardge for setting forth to sea upon a third voyadge to Bantam and the Mollucas ... . with the Dragon, Hector and a pinnace.' In this computation there is an entry of 'lemon water' among 'the proportion of victuals for the two shippes and the pinnace with 280 men'. An editorial footnote adds:

We may trace in this item the hand of Sir James Lancaster who was one of the first to use the juice of lemons as an antidote to scurvy, ... not formally adopted by the Admiralty until 1795, nearly two centuries after its practical efficacy demonstrated by Sir Richard Hawkins and Captain Lancaster. ${ }^{13}$

In the Hawkins Voyages there are published 'The Observations of Sir Richard Hawkins, Knight, on his voyage into the South Sea A.D. I593'.14 Scurvy is fully described in Chapter XVI. He recommends scrupulous cleanliness, physical exercise, including dancing, and also a morning draught of wine or beer. $\mathrm{He}$ concludes with the words: 'That which I have seen most fruitful for this sickness is sower oranges and lemmons, and a water which amongst others (for my particular provision) I carryed to the sea, called Dr. Stevens his water.' Hawkins was as well aware as Lancaster that oranges and lemons were the best cure for preventing scurvy.

The East India Company must have had it established as a regular practice to carry lemons in their ships, because Nixon quotes a letter of complaint from Captain Keeling who sailed in command of the Third Voyage with the Dragon and Hector. ${ }^{15}$ This letter is dated 19 June $16 \mathrm{I}_{5}$ and says: 'Your lemon water in that fleet stark naught, a complaint of the Portuguese and the fleet generally.'

Sir William Foster quotes an account by Nicholas Sharp (p. 42) of the Homeward Voyage of the Charles: 'July 14, 1630. The fleet from England arrived and landed their sick men; but having no orugings and lemons wear not recoveried, but somthing better than they weare.'16

These references seem to dispel the illusion that the East India Company did not do anything about the prevention of scurvy until the appearance of Woodall. It is unlikely that the Dutch were able to keep their health measures so secret that the other companies would have remained in ignorance of them.

At the same time, the structure and purpose of the Royal Navy were entirely different from the fleets of the Merchant Companies, if one may think in modern 


\section{F. F. Tickner and V. C. Medvei}

terms of the Royal Navy at all before the reforms of Pepys. In the seventeenth and eighteenth centuries it was a hard school, and little was done for the welfare of the crews until the mutinies at Spithead and the Nore in 1797. Its task was primarily to keep the narrow seas, and its principal overseas duties took it to the West Indies where citrous fruit was plentiful. Apart from the ships of the Royal Navy which sailed to India to take the surrender of Bombay from the Portuguese in I665, the East India Company was left to maintain its position in the Indian Ocean with its own shipping. At any rate, 'there was no regular and general issue of lemon juice in the Navy in $1795^{\prime}$. Indeed, failure to supply lemon juice was one of the complaints made by the mutineers in $1797 .{ }^{17}$ After all, most of the evidence concerning the efficacy of lemon juice and oranges had been collected and published by James Lind in his work on scurvy in 1757 . Lind, who was Physician to His Majesty's Royal Hospital at Haslar near Portsmouth, earnestly recommended the general use of these fruits in the Navy for the prevention and cure of the scurvy; yet his advice was not heeded by the Lords Commissioners of the Admiralty for nearly another forty years, although the ordinary seamen knew the value of lemon juice by then and resented the lack of its supply. ${ }^{18}$

In the sixteenth century Ronsseus, in a work published in ${ }^{1564}$, mentioned that seamen on long voyages cured themselves of scurvy by the use of oranges.19 He tells the story that Dutch sailors carrying a cargo of oranges were suffering from scurvy on their return from Spain. When eating oranges he thinks they discovered by chance the treatment for scurvy.

Probably citrous fruit juice was not easily procurable in northern Europe at that time, particularly as the Dutch Republic was at war with Spain and Portugal. At any rate the Dutch Company endeavoured to keep its crews healthy principally by trying to shorten the voyage itself and by seeking a better course than crossing the Indian Ocean from the Cape to Sunda Strait in monsoon weather. Fast voyages were encouraged by the payment of a bonus of 600 florins for a voyage under seven months from a Dutch home port to Batavia. The bonus, divided between the master, the merchant in charge, and the two mates, was reduced to 300 florins for a voyage under eight months and 150 for one of less than nine months.

Attempts to find a more favourable course led to the accidental discovery of Western Australia. The Dutch navigators quickly found that the west winds of the south Atlantic persisted beyond the Gape; and in December 16 ro Hendrik Brouwer left Holland with instructions to make trial of a passage in that direction. Sailing due east from the Cape until he judged himself to be in the correct longitude, he turned north to make Sunda Strait successfully. He reached Bantam after a passage of five months and twenty-four days from the Texel, having lost only two men altogether. Six years later Pieter de Carpentier made the same passage with no casualties at all; and from 1617 onwards all Company's ships were instructed to take this course. Occasionally a ship was taken farther east than was necessary, and in this way the western coast of Australia was first sighted by Europeans. 


\section{Scurvy and the Health of European Crews in the Indian Ocean}

During the seventeenth century, ships of the Dutch Company made voyages every year and with varying success. The record passage was that of Gouden Leeuw in I621. She took four months and four days from Goereesche Gat to Batavia and had no casualties at all. In $164 \mathrm{I}$ 's Hartogenbosch took four months and thirteen days with only two casualties, whilst Henrietta Louise took only eleven days longer with ten deaths on the way. In 1664 Jonge Prins reached Batavia in two days under seven months, having lost only three men on the voyage. As a rule, one of the Company's larger ships carried anything from 220 to 280 men. A smaller ship, the fly-boat Nieupoort, took out a crew of eightyseven and thirty-eight soldiers without casualties in 1664 .

On the other hand, bad voyages still occurred in spite of increased knowledge and experience. In $16 \mathrm{I}_{5}$ Vlissingen lost $\mathrm{I}_{3}$ men through lack of drinking water. On 16 September 1647 Princesse Royale left the Texel on her maiden voyage with an unusually heavy complement of 367 persons. By the time she reached the Cape seventy of her company were sick and twenty-six had died. A number of people were then put on shore as unfit for sea, but even so, on the remainder of the voyage she lost a further $105 \mathrm{men}$. She reached Batavia with seventy-five soldiers and I6I passengers and crew.

With difficulties of storage on board ship in the seventeenth century, a call on the voyage at a port where fresh vegetables and fruit were obtainable was the simplest means of maintaining adequate supplies. Nevertheless, the Dutch directors were not anxious that this should be made a pretext for ships to delay their passage, possibly to the detriment of the Company's trade; and a fine of 600 florins was imposed on the master, merchant and mates of a ship which put into port without good reason. However, the bonus for a fast voyage seems to have been so attractive that masters were willing to risk the health of their crews in order to secure it.

After leaving sight of Europe, any port at which a Dutch or English vessel might call before reaching the East Indies was likely to be inhabited either by natives on whom little reliance could be placed or by Spaniards or Portuguese, who were rarely on good terms with the Dutch; the Portuguese were, of course, in alliance with the English after the middle of the seventeenth century. Accordingly, the companies took seriously the idea of cultivating vegetables and even rearing goats and sheep on a remote island. St. Helena ultimately became a 'sea inn', a port of call for the English Company's ships, and a small group of settlers was established in May 1659; but it was too near to Europe for Dutch ships, sailing for Batavia instead of Surat or Bombay. The Dutch for a time occupied Mauritius, but its use involved the crossing of the Indian Ocean in warm latitudes, and at one stage they even took seriously the idea of calling at Amsterdam and St. Paul Islands, between the Cape and Australia, but these were too remote although both had fresh water and Amsterdam Island a good anchorage. For the Dutch Company the only practicable half-way house to India was, therefore, the Cape of Good Hope.

Table Bay was a fair anchorage; fresh water was available in good quantity; and green vegetables could readily be grown there. No organized attempt was 


\section{F. F. Tickner and V. G. Medvei}

made at settlement until the Dutch Company sent an expedition for that purpose under Jan van Riebeeck in $165 \mathrm{I}$, although ships had made it a port of call for half a century previously. Van Riebeeck took with him a gardener named Boom, and under his care the Company's garden soon provided an abundance of fresh vegetables. According to the Journal (Dagh Register) kept in the castle at Batavia, by $166 \mathrm{r}$ the Dutch settlement had 832 vines under cultivation, I,003 citrous fruit-trees and 402 European fruit-trees. Van Riebeeck compiled the Cape Gardener's Almanack; but no special significance can be attached to the fact that he was himself a doctor. He enlisted in the Company's service as an under-surgeon, but he transferred to its administrative staff as soon as he reached Batavia. The directors only put him in charge of the venture to the Cape because the officer who would have been their first choice was not willing to undertake the task.

The call at the Cape, which was specifically excluded from the time reckoned for bonus on a fast voyage, divided the passage to and from the Indies into two.

Medical facilities on board East Indiamen in the seventeenth century were never very good, although they improved with the years. In the second fleet of the English Company in 1604, men ill with the scurvy were 'left to the mercy of God and a small quantity of lemon juice every morning; one physician, shipped for that purpose, being as unwilling as ignorant in anything that might help them-a great oversight in the Company, and will no doubt be better looked to hereafter'. One serious difficulty was lack of candidates for the post of ship's surgeon, for a voyage to the Indies was in those days a remote quest and conditions on board ship were very rough. As we have already mentioned, van Riebeeck transferred to the administrative staff at the first opportunity. Surgeons had far fewer chances than the merchants and ship's officers of making money by private trade.

The Dutch directors retained the services of a surgeon in Amsterdam to examine prospective candidates for employment, whilst the English Company appointed for the same purpose John Woodall of St. Bartholomew's Hospital. Apparently, Woodall was not always able to find competent surgeons, for from time to time the directors expressed disappointment with the quality of his appointments. He also had the task of providing the Company with ships' medicine chests. The Dutch Company employed an apothecary to look after this and to provide medicines for their Indian factories.

Woodall served the English Company for many years and he published an account of the scurvy in his book the Surgeon's Mate in 1639 . He was born about I 590 of an English father and a Welsh mother. As a doctor he had a somewhat chequered career. He was first an Army surgeon and later a surgeon to the colony of English merchants near Posen in Poland. He lived there for eight years and had attacks of the plague twice. In 1604 he went as interpreter to the Czar to negotiate improved trade relations for Charles I. For these services he was apparently appointed the First Surgeon-General of the East India Company, which office he held for thirty years, in 1612. In 1616 he was elected surgeon to St. Bartholomew's Hospital, where William Harvey was his 


\section{Scuroy and the Health of European Crews in the Indian Ocean}

colleague as physician; and he died in 1643 , leaving three sons and a daughter. ${ }^{20}$ He wrote several books, but his literary reputation rests mainly on the Surgeon's Mate ( 1639 ), a copy of which the East India Company compelled every surgeon of their service to possess. Incidentally, it has been said that he was not above accepting bribes in return for commissions, as surgeon in the Gompany's service. But this was fully in accordance with the customs of the day which prevailed for another two centuries. As Surgeon-General he drew up rules for the surgeons, with lists of implements and drugs, and presented candidates for approval to Dr. Atkins and Dr. Winston.

Woodall's references in his Surgeon's Mate are as follows:

Further the Chirurgion or his Mate must not faile to perswade the Governour or Burser in all places where they touch in the Indies and may have it, to provide themselves of juice of Oranges, limes or lemons, and at Banthame of tamarinds. . . . And note for substance, the Lemons, Limes, Tamarinds, Oranges, and other choice of good helps in the Indies which you shall finde there do farre exceede any that can be carried thither from England; and yet there is a good quantity of Juice of Lemons sent in each ship out of England by the great care of the Marchants, and intended onely for the reliefe of every poore man in his neede, which is an admirable comfort to poore men in that disease. . . . The use of the juyce of Lemons is a precious medicine and well tried, being sound and good, let it have the chief place, for it will deserve it.

Thirteen years earlier Captain John Smith compiled his Accidence for Young Seamen (1626), which recommends:

A petty tally of fine white flour, close and well packed, rice, currants, sugar, prunes, cinnamon, ginger, pepper, cloves, green ginger, oil, butter, old cheese or Hollands, wine vinegar, canary sack, aqua vitae, the best wines, the best waters, the juyce of Lemons for the Scurvey, white biscuit, oatmeal, gammons of bacon, dried neats' tongues, roasted beef packed in vinegar, legs of mutton minced and stewed and close packed up with butter in earthen pots.

It is clear that the English Company regularly provided lemon juice for its ships, for in February 1625 the court of directors considered

the demand of the woman, who serves the Company with lemon water, for $12 \mathrm{~d}$. a gallon above the wonted price, pretending the scarcity of lemons; the Court, perceiving this new demand now upon the going of the ships to be a mere trick, resolved to send none, and hereafter to provide it out of Spain, where it is much better than here.

Even at that time, however, scurvy was still rampant on the Atlantic voyages to America. For example, in the Mayflower voyage, 1620, fifty died out of 102 passengers from scurvy and other diseases at the end of its 56 -day journey. Scurvy in fact played a great part in the early settlement of America. In the spring of 1630 about 700 settlers came over in a fleet under the command of John Winthrop and founded Boston. Of those, 200 died by the end of the first year mainly from scurvy. John Winthrop in his History of New England (1631) tells it in the following words:

The poorer sort of people were much afflicted with the scurvy and many died especially at Boston and Charlestown; but in this ship (the Lyon) which arrived in Boston in February, I63 I, came and brought a store of juice of lemons, many recovered speadily. ${ }^{21}$ 


\section{F. 7. Tickner and V. C. Medvei}

Among other foodstuffs, beer was carried at sea in those days, because it kept well, quenched thirst and also acted as a mild antiscorbutic. For this reason a cooper was regularly carried. On the Mayflower John Alden was not an intending pilgrim but a cooper in the ship's crew, and afterwards decided to settle with the colony. The seamen parted with the precious beer only very reluctantly for the use of sick passengers.

As the century went on, both East India Companies learned a good deal about diet and about shipping food in days when cold storage and sterilized packing were unknown. The Dutch at first provided victuals for crews for thirty months since they had no victualling stations in the East; but for soldiers who would stay in the factories and would not undertake the return voyage, food was only shipped for fifteen months. Bread was provided at the rate of four Amsterdam pounds per week per man. (An Amsterdam pound was equivalent to 1.09 pounds avoirdupois.) This would work out at 113,360 pounds avoirdupois for a voyage with a crew of 150 and 100 soldiers.

After the foundation of Batavia in 1619 victualling in the East Indies became possible and supplies were reduced. Bread was provided for twelve months, and from ${ }_{1} 656$ onwards meat and bacon for the same period, or nine months for the smaller ships. Officers usually kept in better health than other ranks since their living conditions were better; and soldiers suffered worse than sailors. Ships with few or no soldiers on board kept healthier crews. Soldiers in the Dutch colonial service in the seventeenth century were invariably of a poor type. Frequently they were men who could make good in no other walk of life, and it is not surprising that many of them died at sea.

Much of our detailed knowledge of the Dutch Company is derived from a survey of its activities written at the end of the seventeenth century by its advocate, Pieter van Dam, who was its secretary as well as its legal adviser. ${ }^{22}$ He gives a list of ship's provisions for 100 men for twenty-seven months. This makes it clear that the value of antiscorbutics was by this time well understood. It included two bottles, each containing half an aam of lemon juice (an aam was equivalent to 150 litres); 112 aams of Spanish wine and 20 pipes of French wine. Wine was issued as an antiscorbutic to the crew, as well as being served as a luxury in the cabin; 20 aams of vinegar were carried, 4 quarter measures of brandy and 100 tuns of beer. The water casks had a capacity of 172 aams; 54,500 pounds of bread were shipped and the meat and fish consisted of $37 \frac{1}{2}$ double tuns of salt meat, 30 tuns of bacon and a supply of Bergen stock-fish, a form of cod, dried and split, obtained by the Dutch Company from Norway and by the English Company from Hull, where its preparation was a staple industry. Cheese was an important Dutch item of diet, and the list provides for 650 cheeses, each weighing seven Amsterdam pounds, as well as 21 tuns of butter; 654 pounds of salt; 2 tuns of barley; 2 aams of vino tinto; 6 tuns of green pease; 12 tuns of grey pease; 75 sacks of groats; 2 tuns of mustard seed and 2 of pepper-root (Mierikswortel), a specific against the scurvy.

A Dutch regulation for the rationing of ships, issued in 1682 , also makes it clear that wine, brandy, pepper-root and wormwood were carried as 


\section{Scurvy and the Health of European Crews in the Indian Ocean}

antiscorbutics; and it prescribes a quarter of an aam of lemon juice as the ration for a hundred men for nine months. Even today the water-supply is probably the determining factor in the period which a ship can remain at sea without revictualling, and although water could be obtained at a number of known places on the way to and from the Indies, it was very necessary to ensure an adequate supply. The Dutch directors always hoped to find a satisfactory method of distilling water at sea. Between 1629 and the end of the century they considered six such projects, one of them from an Englishman, Robert Fitzgerald. The last and most hopeful was from an Amsterdam director, van Collem, but the idea was abandoned after his death in 1707 as too much firewood was needed for fuel. Thus a direct link exists with the modern experiments for converting seawater into drinking water in the case of shipwreck or airwreck over the sea.

It is not the purpose of this paper to quote the celebrated Treatise on the Scurvy by James Lind in detail, because it was not published until 1 753. It should be noted, however, that it was not until the advent of Lind and Captain Cook that the Royal Navy made satisfactory attempts to prevent scurvy, and this was certainly partly influenced by the diseases on Lord Anson's voyage in I 740. It may be possible that the Royal Navy did use fruit juice before that date in individual ships and for individual ship's companies, but it has been pointed out that, for reasons of convenience and economy, in many cases lime juice was used from the West Indies instead of lemon juice. This was also due to the fact that the names lemon and lime had been used by the earlier writers without proper distinction. The juice of the West Indian sour lime is only mildly effective, in contrast to the juice of lemons, oranges, and the Mediterranean sweet lime (which is also akin to the sweet limes of India). This had very bad results in the Royal Navy, and caused the occurrence of further outbreaks of scurvy in His Majesty's ships up to the middle of the nineteenth century. ${ }^{23}$

\section{NOTES AND REFERENCES}

I. Hip pocrates, EEuvres Completes (Littré's ed.), Paris, I85I, viI, 279, 28I.

2. Joinvil le, J. DE, Histoire de St. Louis, publie par N. de Wailly, Paris, 1868.

3. BASHFORD, Sir H., The Harley Street Calendar, 1929, p. I.

4. Chaucer, G. Prologue to the Canterbury Tales, line 434 (Works, ed. Skeat, Oxford, 1894, pp. iv, 13). The Compendium Medicinae of Gilbertus Anglicus has been preserved in several manuscripts; it was printed as Laurea Medicinae at Venice and Lyons in 1510 and at Geneva in 1608. See H. H. Henderson's Gilbertus Anglicus: Medicine of the Thirteenth Century, Cleveland, 1918.

5. Magnus, O., Historia de Gentibus Septentrionalibus, Rome, I555; English translation, London, 1658.

6. Ravenstein, E. G., Fournal of the First Voyage of Vasco da Gama, 1497-9. (Hakluyt Society), 1898.

7. Camoens, L. de. The Lusiad, translated by W. F. Mickle, i798, II, 82.

8. Lind, J., A Treatise on the Scurvy, 3rd ed., 1772; Moore, A. An examination of the chief causes of disease at sea in the era of the Tudors and Stewarts and of the measures taken against it. St. Barth. Hosp. Rep., 1912, XLVII, 67-96. 


\section{F. F. Tickner and V. C. Medoei}

9. Lisle's letter to Suffolk. Cited by Alan Moore (Ref. 8) and M. Oppenheim's History of the Administration of the Navy, 1509-1660, 1896.

10. LinsGhoten, J. H. VAN, Itinerario (Linschoten Society), 1910; English translation of 1598 re-edited for the Hakluyt Society in 1885 .

11. Rouffaer, G. P., and IJzerman, J. W., Eerste Schipvaart der Nederlanders naar OostIndie, The Hague, $1915-35$.

12. Foster, Sir W., The Voyages of Sir James Lancaster to Brazil and the East Indies (Hakluyt Society), 1940.

13. East India Company, Register of Letters $\mathcal{B}^{\circ}$. of the Governour and Company of Merchants Trading to the East, 1600-16rg. Ed. by Sir G. Birdwood, 1893.

14. Hawrins, Sir R., Voyage to the South Seas. In Hakluytus Posthumus, or Purchas his Pilgrimes (Hakluyt Society), 1878, rv.

15. Nixon, J. A., The East India Company and the control of scurvy. Proc. R. Soc. Med. (Sect. Hist. Med.), 1937, xxxu, 193-8.

16. Foster, SIR W., The English Factories in India, 1630-1633, Oxford, 1910, p. 42.

17. Smith, A. Henderson, "A historical inquiry into the efficacy of lime juice for the prevention and cure of scurvy'. F. Roy. Army med. Cps., 1919, xxxin, 93, 188.

18. See letter of Admiral William Waldegrave, 2 December 1797, quoted by A. Henderson Smith (Ref. 17).

19. Ronsse Us, B., De magnis Hippocratis lienibus, Pliniique stomacace ac sceletyrbe, seu vulgo dicto scorbuto, Antwerp, 1564 .

20. MoOre, Sir N., History of St. Bartholomew's Hospital, I918, II, 61 7-22.

21. Winthrop, J., cited by J. B. Nichols, 'Note on the history of scurvy', Ann. med. Hist., 1937, N.S. IX, 286-7.

22. Dam, P. van, Beschryvinge van de Oostindische Compagnie, The Hague, 1927-43.

23. Smith, A. Henderson, loc. cit. (Ref.i 7). 